petition. The goal here is not economic welfare, but the improvement of broadcasting service, ${ }^{83}$ to which increased competition between networks is not relevant. ${ }^{84}$

\title{
CHANGE OF BARGAINING REPRESENTATIVE DURING THE LIFE OF A COLLECTIVE AGREEMENT UNDER THE WAGNER ACT
}

Mosr deep-rooted in importance of the problems emerging under the VVagner Act ${ }^{1}$ are those created by a shift in employees' union allegiance after execution of a contract with their employer. When such a shift occurs, the initial issue before the NLRB involves its power in the face of one union's contract to certify another as bargaining representative of the workers. On the one hand, the statute contains no exception to the Board's administrative duty to investigate and certify when a question as to employee representation arises. ${ }^{2}$ On the other, traditional legal doctrine, left intact by the statute,

83. It is estimated that $82 \%$ of the families in the United States have radios, and that $82.9 \%$ of all radio families listen sometime everyday. See Jourt Counumee o: Radio Researce, Study of Rural Radio Ownership and Use in tire Uinted States (1939) 6. Though there are group variations depending upon urban or non-urban residence, sex, and income, estimates indicate that $60-70 \%$ of all radio owners listen regularly to radio news. See Lazersfeld, Radio and the Printed Page (1940) 231. Perhaps the spoken word has a greater power to influence opinion than the written. See Wilke, An Experimental Comparison of the Spech, the Radio, and the Printed Pagc as Propaganda Devices (1934) 25 Archives of Psrchology.

S4. On December 31, 1941, the Anti-Trust Division brougit two civil suits, one against NBC and one against CBS, charging that these companies monopolized networls broadcasting. N. Y. Times, Jan. 1, 1942, p. 23, col. 2. The relief requested substantially amounts to judicial imposition of the FCC's chain broadeasting regulations, except in relation to divestment of network properties. Whereas Section 3.107 of the chain broadcasting regulations, ordering NBC to sell one of its two networks, was indefinitely suspended to permit orderly disposition of property, and Section 3.106, ordering sale of certain network owned stations, had a time extension provision, the complaints in the anti-trust suits request that the property in question be placed in the hands of a receiver for sale. Aside from the financial effect upon the two network companies the same result will be attained by Government victory in either the network suit against the FCC or the Anti-Trust Division's suits against the network companies.

Intervention of the Anti-Trust Division to secure enforcement of the FCC's regulations emphasizes the ambiguity of the present bases of governmental control over radio networks. A new statute giving the FCC definite regulatory power would eliminate the need of such a back door approach to the problem. It is believed that the new statute should make the FCC's regulatory power exclusive.

1. 49 StAT. 449 (1935), 29 U. S. C. $\$ \$ 151-66$ (Supp. 1939) (hereafter cited by section number only).

2. Section $9(c)$. 
stresses the importance of protecting contractual rights. Moreover, if power to certify is held paramount, there looms the more delicate question of the effect of such action on the continued operation of the existing contract. Refusal to bargain with the newly certified union will subject the employer to an unfair labor practice proceeding; obedience to the administrative mandate may lay him open to a suit on the contract by the displaced representative. ${ }^{3}$ And the problems are accentuated if the contract in question provides for a closed shop in favor of the original union. Certification of a new representative, requiring termination of previous discrimination against employment of its members, would present a critical reversal of relations among employees, their unions and their employer.

As solutions for these problems by the Board or in the courts, three general possibilities are apparent. First, the existence of a valid contract negotiated by the majority representative might be held to eliminate all question as to representation during its term. On the other hand, the contract might be set aside completely on certification of a new bargaining representative. Finally, the conflict could be compromised by recognizing the change in employee allegiance but maintaining the contract binding on employer and employees, either automatically or at the option of the employer. Under the compromise theory, a change of representative would alter an existing contract only by "substituting" the new union for the old under its substantive terms. The choice among these alternatives has become a burning issue in the development of labor law.

\section{The Position of the NLRB}

Power to Certify. ${ }^{4}$ In cases where no contract is involved, the Board has adopted the policy of postponing a change of representative for a reasonable period, usually about a year, after a certification.5 But this policy of postponement, based on a rebuttable presumption of the original union's continuing majority, has been subject to exception on the production of conclusive evidence of an unusually large shift. ${ }^{6}$ Firmly maintaining the primary

3. For the further possibility of a suit by the original union against the new representative for inducing breach of contract, see Galesson, Rival UNIONISM IN THI: United States (1940) 63 et seq.

4. See generally Galenson, op. cit. supra note 3 , at 257-66; Rosenfakb, Tuz NAtional Labor Policy (1940) 263-78, 315; 2 Teller, Labor Disputes and Collective Bargaining (1940) \$\$333-38; Rice, The Determination of Employee Represchtalivics (1938) 5 Law \& Contemp. Prob. 188, 193-200; Rice, The Legal Significance of Labor Contracts under the National Labor Relations Act (1939) 37 Micn. L. Rev. 693. For the Board's own analysis of its cases on this issue, see its annual reports since 1037.

5. See, e.g., U. S. Stamping Co., 5 N. L. R. B. 172 (1938) ; General Motors Corp., 24 N. L. R. B. No. 66, June 22, 1940; cf. Woodside Cotton Mills Co., 21 N. L. R. B. 42 (1940).

6. New York and Cuba Mail S. S. Co., 2 N. L. R. B. 595 (1937); Novelty Slipper Co., 5 N. L. R. B. 264 (1938); Moulton Ladder Manufacturing Co., 31 N. L. R. B. No. 108, May 8, 1941. 
policy of the statute, the Board has refused to limit its discretion in recognizing majority desires as to representation.

When a change in majority allegiance to a particular union appears during the life of a contract, the Board has been similarly reluctant to announce inflexible rules as to the scope of its authority. In no case, however, has certification been denied solely on the ground of the existence of an agreement after the initial year. Although generalization is made difficult by the great variety of factual situations presented and by changes in Board personnel, it is clear that the Board has consistently adhered to the policy that the power to certify cannot be divested by the existence of a contract.

Contracts found illegal because executed or renewed in violation of the terms of the Act are disregarded as a matter of course. Thus, an agreement with a minority union (if a majority exists), or with a union under employer domination or favoritism, cannot bar Board investigation. ${ }^{7}$ A similar illegality attaches if the true majority status of the union was doubtful at the time of the formation or renewal of the agreement. Pendency of a Board proceeding involving union standing, ${ }^{8}$ or presentation to the employer of a formal claim of majority by the rival union, ${ }^{3}$ puts the employer on notice of a dispute as to representation, and no agreement negotiated during the dispute deters the Board from certifying. Where circumstances warrant, moreover, the employer may be held to constructive notice of a dispute which has received no formal recognition..$^{10}$

In cases involving contracts admittedly valid, the Board must proceed with more caution. Recognition of the difficulty of the problem is implicit in the Board's alertness to avoid, whenever possible, a determination of the contract's effect on its power to certify. An agreement in terms conditional on the continuance of the contracting union's majority can of course not be

7. NLRB v. Pennsylvania Greyhound Lines, Inc., 303 U. S. 261 (1938); International Association of Machinists v. NLRB, 311 U. S. 72 (1940).

8. California Wool Scouring Co., 5 N. L. R. B. 782 (1938) (even though the employees later ratified the contract); Silvray Lighting Inc., 18 N. L. R. B. 719 (1939); Jalden Electric Co., 33 N. L. R. B. No. 16, June 30, 1941 (petition filed after the parties had agreed on terms, but before the signing, of the contract). But ef. Superior Electrical Products Co., 6 N. L. R. B. 19 (1938).

9. National Electric Products Corp., 3 N. L. R. B. 475 (1937), (1938) 47 YALE L. J. 799 (despite a court decree of specific performance of the contract by the cmployer) ; Colonie Fibre Co., Inc., 9 N. L. R. B. 658 (1938); Ford Motor Co., 35 N. L. R. B. No. 199, Sept. 30, 1941, N. Y. Times, Oct. 15. 1941, p. 1, col. 4. But of. Hettricl: Manufacturing Co., 25 N. L. R. B. No. 79, July 19, 1940 (postponing election until near end of a one-year contract, since it was for a reasonable period and was entered with the support of the majority).

10. Borg-Warner Corp., 19 N. L. R. B. 538 (1940); General Elcetric Co., 29 N. L. R. B. No. 29, Jan. 23, 1941; Garod Radio Corp., 32 N. L. R. B. No. 163, June 23, 1941 (contract formed with union which got same number of votes in election as petitioning union). But $c f$. National Sugar Refining Co., 10 N. L. R. B. 1410 (1939). 
pleaded in bar. ${ }^{11}$ And when a contract is terminable on notice, ${ }^{12}$ or is near the end of its term ${ }^{13}$ or of the period within which notice of termination may be given, ${ }^{14}$ the Board proceeds to order an election without determining the effect of the contract. A newly certified representative may concededly bargain for a new agreement to take effect on the expiration of the old one, and it is apparently assumed that the new representative may take advantage of termination clauses in the existing contract. In the case of a contract for one year, however, the Board will temporarily deny certification, indulging the presumption of a continuing majority with more force than in the simple case of a previous certification. ${ }^{15}$

But when a valid contract covering all employees has run for more than a year and will not, by its terms, terminate for a year or more in the future, the Board has been compelled to meet the issue. Despite the Board's doubt of its authority, implied by previous avoidance of the problem, it has in such cases unequivocally maintained its duty to certify. The Mctro-Goldzuyn-

11. Wickwire Spencer Steel Co., 18 N. L. R. B. 372 (1939) ; Tennessee Copper Co., 25 N. L. R. B. No. 22, July 6, 1940.

12. Todd-Johnson Dry Docks Inc., 10 N. L. R. B. 629 (1938); Phelps Dodge Copper Products Corp., 29 N. L. R. B. No. 140, Feb. 20, 1941 (following strike by members of petitioning union, existing contract modified to provide for termination on notice); General Motors Corp., 32 N. L. R. B. No. 51, June 2, 1941. This is particularly true where the contracting union has ceased to function. Sound Timber Co., 8 N. L. R. B. 844. (1938); Fischer Lumber Co., Inc., 31 N. L. R. B. No. 136, May 13, 1941.

13. Martin Bros. Box Co., 7 N. L. R. B. 88 (1938); Brown-Saltman Furniture Co., 7 N. L. R. B. 1174 (1938); I. Miller \& Sons, Inc., 13 N. L. R. B. 691 (1939).

14. Utica Knitting Co., 8 N. L. R. B. 783 (1938); Heldman-Schild-Lasser, Inc, 11 N. L. R. B. 1289 (1939). See Gowanus Towing Co., Inc., 8 N. L. R. B. 820,824 (1938) (one-year contract for a preferential shop).

15. See especially Pacific Greyhound Lines, 22 N. L. R. B. 111,131, n. 57 (1940). This practice has been followed with considerable regularity. See Superior Electrical Products Co., 6 N. L. R. B. 19 (1938); J. E. Pearce Contracting and Stevedoring Co., Inc., 20 N. L. R. B. 1061 (1940); Lewis Bolt and Nut Co., 23 N. L. R. B. 708 (1940). Adherence to the one-year rule by the present Board (Chairman Millis, Members Leiserson and Reilly) is indicated by Pressed Steel Car Co., Inc., 36 N. L. R. B. No. 117, Oct. 31, 1941 (despite doubling of number of employees since execution of contract). But $\mathrm{c}$. Food Machinery Corp., 36 N.L.R.B. No. 98, Oct. 30, 1941 (election ordered after closed shop contract had run only six months where original union had become intetive).

Difference of opinion among the members of the Board has been particularly apparent in cases where an existing one-year contract has been extended for another ycar. $A$ petition for election filed during the extension period will usually be postponed in the absence of sufficient evidence to rebut the presumption that the original union maintaincd its majority through the first year. See National Sugar Refining Co., 10 N. L. R. B. 1410 (1939); American Hair \& Felt Co., 15 N. L. R. B. 572 (1939); Utica Knitting Co., 23 N.L.R.B. 55 (1940); Hettrick Manufacturing Co., 25 N. L. R.B. No. 79, July 19, 1940; Eaton Manufacturing Co., 29 N. L.R.B. No. 12, Jan. 16, 1941. But $c f$. Radio Wire Television, Inc., 30 N. L. R. B. No. 131, April 4, 1941 (evidence of a shift was conclusive). 
IIayer case, ${ }^{16}$ for example, involved a collective agreement for five years. In granting a petition for election filed after the agreement had run one year, the Board dismissed defenses based on the contract with a simple reiteration of its belief that employees' choice of bargaining representative could not be shackled for an unduly long period merely by the existence of a contract. Similar statements have accompanied similar holdings in several more recent cases, ${ }^{17}$ or have been offered as alternative support in cases where another more settled ground for the decision has been present.1s

The fact that a contract has a long unexpired term, or has no termination date, ${ }^{19}$ is regarded only as increasing the necessity for an election. Similarly, the presence of a closed or preferential shop clause in an existing agreement, because it tends to freeze the status of the present representative and to make employees reluctant openly to announce their change of union membership, induces additional solicitude in ascertaining current employee sentiment. ${ }^{20}$ Although contract arguments against administrative interference in such a situation are particularly persuasive, ${ }^{21}$ they have not induced the Board to make an exception to its general policy in favor of certification."2 In all situations, therefore, the Board allows a different union to assume all the rights of the statutory bargaining representative for all the employees.

16. Mietro-Goldwyn-Miayer Studios, 7 N. L. R. B. 662, 697 (1938). See also Hubinger Co., 4 N. L. R. B. 428 (1937).

17. 11. \& J. Tracy, Inc, 12 N. L. R. B. 936 (1939); Volupte, Inc, 22 N. L. R. B. 1029 (1940) ; Rosedale Knitting Co., 23 N. L. R. B. 527 (1940); Lewis Steel Produrts Corp., 23 N. L. R. B. 793 (1940); Kahn \& Feldman, Inc, 30 N. L. R. B. No. 45, MIarch 13, 1941 ; Presto Recording Corp., 34 N. L. R. B. No. 3, Aug. 8, 1941.

18. Columbia Broadcasting System, Inc., S N. L. R. B. 503 (1938); Colenie Fibre Co., Inc, 9 N. L. R. B. 658 (1938) ; Showers Brothers Co., Inc., 13 N. L. R. B. $\$ 29$ (1939); American Hair \& Felt Co., 21 N. L. R. B. 570 (1940); Gulf Refining Co., 21 N. L. R. B, 1033 (1940).

19. Seiss Manufacturing Co., 7 N. L. R. B. 481 (1938); Standard Sted Spring Co., 18 N. L. R. B. 713 (1939).

20. The Board has recognized this in requiring less proof of majority in granting elections on the petition of outside unions in sone such cases. George W. Borg Corp., 25 N. L. R. B. No. 58, July 16, 1940; Belmont Radio Corp., 27 N. L. R. B. No. 78, Sept. 20, 1940; Oregon Plywood Co., 33 N. L. R. B. No. 206, Aug. 7, 1941. On the other hand, the possibility of similar coercion was not considered significant in Hettricl: Manufacturing Co., 25 N. L. R. B. No. 79, July 19, 1940, or Beaunit Miills, Ine., 33 N. L. R. B. No. 45, July 8, 1941.

21. See opinion of Chairman Madden in Ansley Radio Corp., 18 N. L. R. B. 1023, 1058 (1939) ; J. E. Pearce Contracting and Stevedoring Co., 20 N. L. R. B. 1061 (1940): S. E. \& M. Vernon Inc, 24 N. L. R. B. No. 75, June 15, 1940; Douglas and Lomason Co., 34 N. L. R. B. No. 8, Aug. 9, 1941. Edwin Smith dissents in ezch of these cases. See also concurring opinion of Leiserson in Presto Recording Corp., 34 N. L. R. B. No. 3, Aug. 8, 1941, at 6 .

22. See Pacific Greyhound Lines, 22 N. L. R. B. 111, 131, n. 57 (1940). Closed shop contracts were involved in the following cases in which elections were ordered: 1I. \& J. Tracy Inc., 12 N. L. R. B. 936 (1939); Borg-Warner Corp., 19 N. L. R. B. 
Effect of Change of Representative on the Existing Contract. When certification is granted during the life of an agreement, the Board manifests justifiable reluctance to commit itself on the effect of its action. Since it is not charged with the enforcement of contracts the Board feels no duty to promulgate rules concerning them..$^{23}$ But the conflict implicit in the situation is so clear that the Board has recognized the necessity for some solution. While it is apparent that the Board will not allow the existence of an agreement to preclude all change, on the other hand it has not suggested absolute abrogation of the contract. Either doubt as to its authority ${ }^{24}$ or respect for whatever rights may have been secured by the contract ${ }^{25}$ has apparently led the Board to support the "substitutionary" doctrine.

In cases where a change in national affiliation has been accomplished by a union local acting as a body, Board insistence on substitution is clear. ${ }^{20}$ Much more usual, however, is a shift in union membership by a simple majority of employees acting as individuals. In an early case on such facts, ${ }^{27}$ the Board referred with approval to the substitutionary theory as mitigating the severity of its refusal to be precluded by the existing contract. Though this statement was affirmed in its early annual reports, ${ }^{28}$ the Board's official position in the case law has again become doubtful; a policy of stbstitution has been consistently advocated only in separate opinions by former Member Edwin Smith, ${ }^{20}$ other members for the most part remaining conspictously

538 (1940); National Battery Co., 28 N. L. R. B. No. 128, Dec. 31, 1940. Existence of an injunction, ordering the employer to hire only members of the contracting union, has not deterred the Board from ordering an election, though the contract is valid. Transformer Corp. of America, 26 N. L. R. B. No. 44, Aug. 10, 1940; Presto Recording Corp., 34 N. L. R. B. No. 3, Aug. 8, 1941.

23. See concurring opinion of Leiserson in Presto Recording Corp., 34 N. L. R. B. No. 3, Aug. 8, 1941, at 6 .

24. See ibid.

25. See cases cited supra note 21 .

26. M. and M. Wood Working Co., 6 N. L. R. B. 372 (1938); Smith Wood Pro= ducts, Inc., 7 N. L. R.B. 950 (1938); Transformer Corp. of America, 26 N. L. R. B. No. 44, Aug. 10, 1940. But cf. Douglas and Lomason Co., 34 N. L. R. B. No. 8, Aug. 9, 1941.

27. New England Transportation Co., 1 N. L. R. B. 130 (1936). "The whole process of collective bargaining and unrestricted choice of representatives assumes the frecdom of employees to change their representatives, while at the same time continuing the existing agreements under which the representatives must function." Id. at 138 .

28. 1 NLRB ANN. Rep. (1936) 108; 2 id. (1937) at 118. It is noticeable, however, that no mention is made of substitution in subsequent annual reports of the Board.

29. Dissenting in National Sugar Refining Co., 10 N. L. R. B. 1410, 1415 (1939); dissenting in American Fiair \& Felt Co., 15 N. L. R. B. 572, 579 (1939); concurring in Pacific Greyhound Lines, 22 N. L. R. B. 111, 144 (1940); separate opinion, for the Board, in Utica Knitting Co., 23 N. L. R. B. 55, 60 (1940); concurring in Detroit \& Cleveland Navigation Co., 29 N. L. R. B. No. 33, Jan. 24, 1941, at 6; dissenting in Douglas and Lomason Co., 34 N. L. R. B. No. 8, Aug. 9, 1941, at 7. 
silent. Proponents of this compromise device, moreover, admit that even it is inadequate to sustain the continuance of closed shop clauses."

Justification for the Board's Position. Writers on the subject, assuming legislative enactment of the ideal norm of industrial government, have hastened to offer theoretical support for the Board's assertion of administrative authority over collective labor agreements. They emphasize that the primary purpose of the Wagner Act is to insure democratic majority control of the relations of workers with their employer. ${ }^{31}$ The position of a national union organization is considered that of a purely incidental conduit for the free expression of employee will. It follows that a union losing majority support simultaneously loses authority to bargain for the employees. From this point of view, considerations of industrial stability, while important in the administration of the statute, cannot justify sterilization for an unreasonable term of the workers' right to continuously accurate representation. MIoreover, any contractual attempt to compel employee submission to representation no longer supported by the majority would be a certain cause of industrial unrest. These conclusions are allegedly implicit in the statutory command and cannot be circumvented by private contractual arrangements. ${ }^{32}$

Apart from the requirements of the statute, it has been further pointed out that contract arguments fail to offer a conclusive defense to Board intervention. It was largely by mechanical assumption that labor agreements were originally assimilated into the contract category. ${ }^{33}$ Traditional individualistic contract doctrine has proved inadequate when applied to agreements essentially collective and governmental. Their social and industrial importance $^{34}$ is inconsistent with the restriction of their benefits to the

30. For Smith's opinion that such clauses must become inoperative on the change of representative, see Pacific Greyhound Lines, 22 N. L. R. B. 111, 144 (1940), which contains his most complete statement of the effects of substitution, and his opinion in Ansley Radio Corp., is N. L. R. B. 102S, 1066 (1939).

31. For discussion of the adoption and the application of the principle of majority rule, see Rosenfarb, The National Labor Polic: (1940) c. IX; Latham, Lcgislatizec Purpose and Administrative Policy under the National Labor Relations Aet (1936) 4 Geo. WASE. L. Rev. 433, 449.

32. See, e.g., Amendments to the IWagner Act: II (1939) 7 Inr. Junw. Ass': Bunb. $85,94$.

33. For the development of the labor agreement, through the status of mere "usage" or "gentlemen's agreement," to a modified legal enforceability, see 1 TEuLE, Laros Disputes and Collactive Bargaining (1940) \$\$154-68; Witmer, Collectiv' Labor Agrecments in the Courts (1938) 48 Yare L. J. 195; Pipin, Enforcement of Rights under Collective Bargaining Agreements (1939) 6 U. of CHI. L. REv. 651; Rice, Collcelize Labor Agreements in American Law (1931) 44 HARv. L. KEv. 572, 581.

34. For a closed shop contract held valid even though the same union held such contracts covering $95 \%$ of the employees in the industry in the region, see F. F. East Co., Inc. v. United Oystermen's Union 19600, 21 A. (2d) 799 (N. J. Ct. Errors and App. 1941). 
immediate parties. Straightforward recognition of their quasi-legislative character, it is argued, ${ }^{35}$ would clear the way for a more realistic approach.

Even conceding that collective agreements should be warped into ordinary contract moulds, traditional doctrine, expanded to meet the requirements of a new legal form, may be invoked to justify the Board's position. Under third party beneficiary doctrine, usually cited in opposition to the Board, employees could be held entitled to disclaim the benefits of the contract. ad Since, however, this rationale is postulated on a controlling and independent position for the union, its validity under the Wagner Act is questionable. Recognition of an independent legal right in the union no longer has the support which it mustered when agreements could be negatiated irrespective of questions of majority representation. The theory customarily invoked, therefore, is that the majority of the employees, as an entity under the statute, is the true party in interest to the contract, holding rights through the agency of the union representative. ${ }^{37}$ Thus any exclusive interest claimed by the agent is defeasible at the will of the principal. And since the principal remains the same after an election to shift agents, "substitution" can be justified as effecting no material change in the legal rights or obligations of the majority entity. ${ }^{38}$

\section{The Position of the Courts}

Attack on the Board's Conclusions. In the courts and before Congress, ${ }^{\text {an }}$ employers and contract-holding unions have urged considerations directly opposed to those adopted by the Board. They have relied on the Act's emphasis on the necessity for elimination of the recurrent disruptions in

35. TeLLER, op. cit. supra note 33, at \$§ 172-77; Witmer, supra note 33, at 195-99, 221; Duguit, Collective Acts as Distinguished from Contracts (1918) 27 Y YLE L. J. 753. This has been largely accomplished in some foreign countries. See itfrat note 85.

36. See Restatenent, Contracts (1932) §137. This argument, however, has not been adopted, since it neglects the concurrent benefits to both union and employer under the contract.

37. See, e.g., Larson, The Labor Relations Acts-Thcir Effect on Industrial Warfare (1938) 36 Mich. L. REv. 1237, 1254.

38. See Note (1939) 48 Yale L. J. 1059, 1064; of. National Fed. Ry. Workers v. NMB, 110 F. (2d) 529, 532 (App. D. C. 1940), cert. dented, 310 U. S. 628 (1040) : "The fact that employees have amicable relations with their employers does not, however, preclude the existence of a dispute inter se as to the representative for collectivo bargaining purposes."

39. In the turbulent controversy which arose in 1938 around the Act and its administration, several amendments were proposed specifically restricting the authority of the Board. One of these, the Walsh bill [S. 1000, 76th Cong., 1st Sess. (1939)], was introduced on behalf of the AFL. It contained $[\S 10(\mathrm{e})]$ a declaration that the union has an interest in its own right in the contract, and that a change of affiliation by the employees should not affect the rights of the union until one year after the execution of the contract. See Amendments to the Wagner Act (1939) 7 INT. Jukiv. Ass'v Bult. 73, 85; Legis. (1939) 52 Harv. L. Rev. 970, 978. 
industrial relations. ${ }^{40}$ In enforcing negotiation by employers the statute requires willingness to put the results into legally enforceable form. ${ }^{11}$ No maximum is set for the term of the contract, and closed shop agreenents are specifically not prohibited.2 The contract culminating the statutory hargaining process must, to be effective, be binding on both parties. The cmployee, it is argued, deliberately agrees to a limitation on his right to change representative, in return for the benefits of participation in the agreement negotiated by the union. . $^{43}$

The facts of union organization and labor relations, moreover, are involied to deny the power claimed by the Board. In the typical situation the lalur agreement is conceived and negotiated by officials of the central union organization, supported in their demands by a bargaining strength far greater than that of the particular local union. ${ }^{44}$ The employer, correspondingly, must measure his concessions by the bargaining strength and the reliability of the union with which he is negotiating. A decisive alteration in his position would follow the "substitution" of a new party entitled to enforce the contract against him. ${ }^{45}$ On the other hand, it is said that the interest of the union in the contract should not be limited to the interest of the single unit covered by it. As a source of strength in industry as a whole, the contract is of vital importance to the union organization and all its members. Particularly in the case of a closed or preferential shop provision, the contract has the immediate value of possible future livelihood to other union members in the locality. ${ }^{46}$

These facts gain significance, according to opponents of the Board, in the application of contract law to the controversy. Despite the decree of the statute that bargaining is legitimate only if done by the representative of

40. Section 1; see Consolidated Edison Co. v. NLRB, 305 U. S. 197, 236 (1938).

41. H. J. Heinz Co. v. NLRB, 311 U. S. 514 (1941), aff'g 110 F. (2d) 843 (C. C. A. 6th, 1940), enfg 10 N. L. R. B. 963 (1939). On the extent of this requirement, sce Daykin, Social and Legal Implications of Collectice Bargaining muder the NLR.1 (1941)

21 B. U. L. Rev. 212, 227 et seq.

42. Section $8(3)$.

43. de Vyver, The Intra-Union Control of Collectice Bargaining (1938) 5 L.w \& Contearp. Prob. 288, 294.

44. Id. at 299 and passim.

45. "These [new] representatives are of course free to bargain concerning changes in the existing arrangements . . " New England Transpurtation Co., 1 N.L. R.B. 130, 139 (1936), cited supra note 27. But under the Norris-La Guardia Act, existence of a valid contract will not ground an injunction against striking or piclieting in support of demands contrary to terms of the contract. 47 STaT. 70 (1932), 29 U. S. C. $\$ 101$ (1934) ; Fur Workers Union, Local No. 172 v. Fur Workers Union, 105 F. (2d) 1 (App. D. C. 1939); Iund v. Woodenware Workers Union, 19 F. Supp. 607 (D. Afinn. 1937). 46. See 3 Encrc. Soc. Scierces 568, 570; cf. Pa. Lab. Rel. Bd. v. Rcd Star Shoz Repairing Co., Inc, 1 C. C. H. Labor Cases 66S, 669 (Pa. C. P. 1938); Masun Manufacturing Co. v. United Furniture Workers of America, Local No. 576, 2 L.iv. REs. Res. S38 (Cal. Super. Ct. 1938). 
the majority, the union is entitled to claim definite interests in its own right under a contract. Conclusions drawn from the principal-agent theory of collective agreements are therefore rejected as unrealistic. The majority entity of the employees should allegedly be regarded rather as a passive third party beneficiary of the contract negotiated by the union. ${ }^{\mathbf{} 7}$ Under this rationale, one group of employees may not elect to terminate the rights and liabilities of the principal parties after accepting the benefits of the contract. Substitution can be justified only under principles of novation, which require consent by the employer or by both original parties. ${ }^{48}$ To make an employer's rights dependent on the will of his employees, moreover, violates a fundamental contract requirement which the statute cannot be invoked to eliminate. ${ }^{40}$

Judicial Attitude toward Substitution. The courts have tended to accept these arguments in preference to those supporting the Board. Although final judicial pronouncement until recently has been lacking, ${ }^{50}$ it has been generally apparent that a labor agreement would be strictly enforced as creating property rights in the union whose name appears on the contract instrument. ${ }^{61}$ The specific terms and the "intent of the parties" have been examined for indications of the party in interest. ${ }^{52}$ If the contract has been found to run to a national or to a local union embracing more than the particular unit covered by it, it is necessarily immune from repudiation by a mere majority of the employees in that unit. ${ }^{53}$

Even in the rare case of a contract held by a one-tnit local, moreover, a change in representative is not allowed to affect the terms of the agreement. It has been held that a local may, by a technically perfect transfer of national affiliation, continue to exercise contract rights acquired while under the former affiliation. ${ }^{64} \mathrm{But}$ the obstacles to complete secession and reaffiliation are almost insuperable, even admitting compliance with the constitution or

47. A majority of the courts have adopted this legal theory in their treatment of collective agreements. See 1 Teller, Labor Disputes and Collective Bargaining (1940) $\$ \$ 167,168$; Mason Manufacturing Co. v. United Furniture Workers of America, Local No. 576, 2 Lab. Rez. Rep. 838 (Cal. Super. Ct. 1938).

48. See Restatement, Contracts (1932) $\$ 430$.

49. For the employer's practical reaction to the situation, see RiNCKHory AND Rector, Procedure and Practice Under the NLRA (1940) 96, stating that an existing contract will become void if another union is certified.

50. The delay is attributable to the fact that there is no appeal from a certification or an order for an election by the Board. AFL v. NLRB, 308 U. S. 401 (1940); NLRB v. Falk Corp., 308 U. S. 453 (1940).

51. See Note (1939) 48 Yale L. J. 1059, 1060; (1940) 38 Mrcu. L. Rev. 516, 519.

52. $M$ and $M$ Wood Working Co. v. NLRB, 101 F. (2d) 938 (C. C. A. 9th, 1939), 48 YALE L. J. 1059, setting aside 6 N. L. R. B. 372 (1938), cited supra note 26; United Electric Coal Cos. v. Rice, 80 F. (2d) 1 (C. C. A. 7th, 1935), (1936) 45 Yale L. J. 1320. The' vagueness of the criteria for this determination is illustrated by the Woodworkers case.

53. See cases cited stpra notes 47 and 52.

54. See Note (1939) 48 Y YLE L. J. 1059, 1061, n. 17 and cases cited. 
charter of the national union. A finding that the local has been disbanded and recreated may mean the termination of its rights; ${ }^{35}$ on the other hand, a small group remaining in the original affiliation may retain all rights of the local. "It follows that a transfer of union support by the simple majority sufficient for Board certification cannot, at least in current judicial atmosphere, divest the original representative of its rights under an agreement with the employer.

Judicial Attitude toward Abrogation. In the light of the limitations imposed on the possibility of substitution, it is natural for the courts to resist administrative attempts to set aside a contract on the certification of a llew: representative. The Circuit Court of Appeals for the Sixth Circuit, in the recent Electric Vacumm Cleaner Company case, ${ }^{67}$ has left little doubt of its opposition to the Board. Here, an AFL local held a wage contract for one year. An oral agreement for a preferential shop had accompanied the contract, but had not been posted with it nor read in union meetings. Shortly after renewal of the contract a CIO movement began. Following a CIO strike protesting the discharge of an employee for refusing to join the AFL, the plant was closed at the request of the AFL. During the shut-down the CIO local made a formal claim of majority and filed a petition for election with the Board. Later the company executed a closed shop contract with the AFL and re-opened, hiring only AFL men. A great majority of the employees then returned to work as AFL members.

On these facts the Board ordered the employer to cease giving effect to the closed shop contract and directed that an election be held, offering familiar grounds for its decision. ${ }^{58}$ Having no notice of the purported preferential shop agreement, the men were held wrongly discharged for failing to support the AFL.99 Since the acts of employer assistance to the AFL were illegal, and since there had been previous notice of a dispute as to representation, the subsequent closed shop contract was declared invalid. The Sixth Circuit, however, denied the Board's petition for enforcement of the order against the employer. The company's assistance was justified on the ground that notice of the preferential shop agreement to officers of

55. See, e.g., Matter of Klinger v. Krum, Inc., 259 App. Div, 309, 19 N. Y. S. (2d) 193 (1st Dep't 1940).

56. For even stronger judicial opinion against substitution, see $\mathrm{MI}$ and $\mathrm{M}$ Wood Working Co. v. Plywood \& Veneer Workers Local No. 102, 23 F. Supp 11, (D. Ore. 1938), in which the court states that its decision would be the same even if the shift had been unanimous. This case also contains the suggestion that the original affiliation could not be ended in any case without consent of the parent.

57. NLRE v. Electric Vacuum Cleaner Co., Inc., 120 F. (2d) 611 (C. C. A. Gth, 1941), cert. granted, 10 U. S. L. WeEK 3129 (U. S. 1941).

58. Electric Vacuum Cleaner Co., Inc., \& N. L. R. B. 112 (193\$).

59. The Board held further that in no event could a preferential shun cuntract justify many of the acts of the company. 8 N. L. R. B. 112, 118 (1938). It is to review the Circuit Court's reversal on this point that certiorari has been granted. 
the union local constituted notice to all the members. Because the original contract was in effect and the employees had not withdrawn their AFL authorizations, it was held that the AFL was still the representative at the formation of the closed shop contract, and that contract was therefore valid. The court noted, however, that the original contract was for a reasonable term, and that no other bargaining representative had been certified. ${ }^{00}$

Implications of the possibility of an approach more favorable to the Board's position are contained in the recent $M c K e s s o n$ \& Robbins case. ${ }^{61}$ Sustaining the Board's conclusion that an intra-AFL truce agreement did not preclude certification after one of the conflicting AFL unions removed to the CIO, the Court of Appeals for the District of Columbia held invalid a closed shop contract with the remaining AFL union executed during the dispute. ${ }^{\circ 2}$ The current conflict on the issues involved in the general problem is illustrated in Klein $v$. Herrick, ${ }^{63}$ in which the District Court for the Southern District of New York refused to enjoin an election ordered during the term of a closed shop contract. The court assumed jurisdiction on the theory that the possibility of a newly certified union negotiating changes in the existing contract created a danger of legal injury, ${ }^{64}$ but denied relief on the

60. $120 \mathrm{~F}$. (2d) $611,615-16$ (C. C. A. 6 th, 1941). The reasoning of the court is typical: "The express purpose of the statute was the establishment of industrial peace, and the [closed shop] proviso was enacted to give the employer the opportunity of dealing in an orderly fashion with one organization only, instead of with various conflicting organizations. . . The Congress would not have specifically authorized a contract of this nature unless it had intended that both parties should be bound thereby. . . . If the one-year term limits the freedom of the employees at will to discard membership in one union for membership in another, the limitation has been freely agreed to by the men themselves . . ." For very similar treatment of the problem, sec Peninsular \& Occidental S. S. Co. v. NLRB, 98 F. (2d) 411 (C. C. A. 5th, 1938), ccrt. denicl, 305 U. S. 653 (1938), setting aside 5 N. L. R. B. 959 (1938).

61. NLRB v. McKesson \& Robbins, Inc., 121 F. (2d) 84 (App. D. C. 1941), 28 VA. L. Rev. 100, cert. denied, 10 U. S. L. WeEK 3138 (U. S. 1941), enf'g McKesson \& Robbins, Inc., 5 N. L. R. B. 70 (1938).

62. Though this decision is based on construction of the terms of the truce agrecment itself, the court intimates that it would have reached a similar decision regardless of the intent of the agreement: "It did not purport to bind the unions as such not to change affiliation. But even if it had done this, that would be very different from binding the individual members likewise to retain affliation." 121 F. (2d) 84, 92 (App. D. C. 1941).

63. 41 F. Supp. 417 (S.D. N.Y. 1941). This was an application by the AFL union holding the existing closed shop contract which the Board had disregarded in Presto Recording Corp., 34 N.L. R.B. No. 3, Aug. 8, 1941, cited sispra note 17.

64. 41 F. Supp. at 419-23. Citing $A F L$ v. Madden [33 F. Supp. 943 (D. D. C. 1940)] and International Brotherhood of Electrical Workers v. NLRB [41 F. Supp. 57 (E. D. Mich. 1940)], the court held that an injunction might be available against a wrongful election order by the Board even though no appeal from the order could be had. In neither of these cases, however, was the injunction predicated on the cxistence of a contract; the Board orders complained of had totally excluded the petitioning unions from the ballot. For a case refusing to base an injunction on the existence of at contract, 
ground that the damage anticipated in the particular situation was too remote and uncertain. Reserving decision on the effect of certification of the rival union, the court noted that the contract might continue specifically enforceable regardless of the outcome of the election, but suggested the possibility of substitution "with the consent of the employer," on the basis of the agency theory of union representation. ${ }^{65}$ While the federal courts have thus skirted the periphery of the main problem, the New York courts have met it head-on. One lower state court has produced a definitive denial of such authority in the National Board. In Labarge v. Malone Alunimum Corporation, ${ }^{60}$ where the Board had certified one union during the life of a contract in favor of another, the employer had then entered into a contract with the new representative. At the instance of the first union, performance of the second contract was enjoined.

The most authoritative and the most definite opposition to the Board's position has emerged in the recent Triboro Coach Corporation decision by the New York Court of Appeals. ${ }^{67}$ The controversy arose between two rival unions under the state Labor Relations Act.69 Amalgamated Association, an AFL local, held a closed shop contract for three years, ${ }^{\text {c9 }}$ renewable automatically in the absence of notice of termination ninety days before the end of its term. After this agreement had run one year, CIO's Transport Workers Union conducted a membership drive, and petitioned the Board for an election of representative by employees. The Board first granted the petition, but on rehearing denied it, making an exception to established practice solely on the ground that the contract in question was executed before

see Amalgamated Meat Cutters \& Butchers Workmen of North America v. Spreckels, 119 F. (2d) 64 (C. C. A. 9th, 1941).

65. $41 \mathrm{~F}$. Supp. at 424 . The interesting suggestion is added that the Buard's action "may rez'eal but not create" the fact of a shift.

66. 3 C. C. H. Labor Cases $60,057,6$ Lab. Ret. Rep. $S 87$ (N. Y. Sup. Ct. 1940). "The Act does not confer upon the Labor Board authority to invalidate contracts with independent labor organizations. . . . The initial contract in question, between members of a union and their employer, established property rights which the courts, if possible, should protect and should not surrender to a Board whose authority to invalidate them has not been specifically given." Id. at 60,05S, 6 LAr. REL REp. at 888 .

67. Triboro Coach Corp. v. NYSLRB, 286 N. Y. 314,36 N. E. (2d) 315 (1941) (Lehman, Loughran and Desmond dissenting), 90 U. of PA. L. REv. 225. Motion for rehearing was filed Oct. 11, 1941. On the lower court opinion, see (1941) 41 Cor. L. REV. 524.

68. N. Y. LAEOR LAW $\$ \$ 700-16$. The right to bargaining representatives of the free choice of the employees is also granted by N. Y. Consr. (1938) Art. I, $\$ 17$. The New York statute is substantially identical, for present purnoses, with the Wagner Act. The NYSLRB has also developed a certification practice identical with that of the National Board. See NYSLRB REP. (1939) 104-17; id. (1940) at 73-E0.

69. This contract with Amalgamated, at the time the only labor organization in the field, had been signed before Triboro had started its omnibus service or had hired any employees. See 286 N. Y. 314, 329, 36 N. E. (2d) 315, 321 (1941). 
the effective date of the statute. ${ }^{70}$ Toward the end of the period within which notice of termination might be given, officials of the AFL national began negotiations for a new contract. On the day the period ended ${ }^{71}$ Transport again sought an election. The Board granted the petition for election ${ }^{72}$ but twice postponed the date for holding it at the request of Amalgamated. Before that date Amalgamated had concluded another three-year closed shop contract with the company. Though this contract was ratified by the employees as members of Amalgamated, a majority voted at the subsequent election to be represented by Transport. Pleading its AFL contract, however, the employer refused to bargain with the CIO local.

On unfair labor practice charges filed by Transport, the Board ordered Triboro to recognize and bargain with Transport, basing its decision on three alternative grounds: ${ }^{73}$ The original contract was found to have been terminated during the negotiations for the new one. The second contract was held invalid because it had been executed during the pendency of a representation proceeding. And in any event, since the employees had never voted on the question, they could no longer be barred from effectuating their desires as to representation.

The Court of Appeals, affirming a judgment of the lower court ${ }^{74}$ setting aside the Board's order, specifically denied each of the Board's arguments. The finding of termination of the first contract was held to be without factural support. Since the agreement provided for a closed shop, a fortiori it constituted Amalgamated the representative of the employees throughout its life; nor could this immutable fact be altered by administrative notice of a representation question. ${ }^{75}$ To emphasize its position on the basic issue, the

70. 2 L. R. R. MAN. 566, 567 (1938).

71. It was so treated by the court. Dealing with the deadline for notice of termination, the contract specified "ninety days" before the end of its term; Transport's petition, however, was filed three calendar months, in this case 92 days, before the end of the life of the contract. Thus the petition was actually two days within the period for notice. It was principally on this ground that rehearing has been asked. See Bricf for NYSLRB on Notice of Motion for Reargument, filed Oct. 11, 1941.

72. 5 L. R. R. MAN. 630 (1939). Some of the members of Transport, in danger of discharge under the closed shop contract, had sought to enjoin its performance. The suit was dismissed for want of jurisdiction, though the court indicated its belief that Triboro had been guilty of unfair labor practice. Domanick v. Triboro Coach Corp., 18 N. Y. S. (2d) 650 (Sup. Ct. 1940). In a second action between the same parties a temporary injunction was granted pending Board decision, but this was reversed on appeal. 173 Mfisc. 911, 18 N. Y. S. (2d) 960 (Sup. Ct. 1940), rev'd, 259 App. Div. 657, 20 N. Y. S. (2d) 306 (1st Dep't 1940).

73. 6 L. R. R. MAN. 631 (1940).

74. 22 N. Y. S. (2d) 1013 (Sup. Ct. 1940), aff'd, 261 App. Div. 636, 27 N. X. S. (2d) 83 (2d Dep't 1941).

75. "By waiting until the expiration of the period during which such notice might be given, the employees have in effect made a choice that Amalgamated is to be their representative for the next three years ..." 286 N. Y. 314, 320, 36 N. E. (2d) 315, 317 . 
court addressed itself directly to the question "whether employees who have made a valid contract with their employer may, while the contract is in force, choose another union as their representative to repudiate the contract." The answer was unequivocal that "there is nothing in this right of union members to select a new bargaining representative which would impair the sanctity of the obligations of the existing contract . . "70

\section{The Legislative Problear}

Limitations on the right of employees to freedom of choice of representation, clear in the New York courts and discernible in the tenor of federal decisions, threaten destruction of the fundamental accomplishment claimed for the Labor Relations Act. If the present judicial attitude prevails, change of representative will be held ineffective during a valid agreement for whatever term. But the courts have gone further, challenging the basis of more settled administrative practice. It appears that a closed shop contract may be held by nature conclusive of representation for the purposes of negotiation even as to the future. In the absence of an officially proven shift, the authority of the existing formal representative may not be terminated by mere doubt as to its continuing majority status. Thus an outside union must, to prevent extension of an existing contract, establish a bargaining position during the term of the contract. Its difficulties in obtaining and proving a majority are increased by the employer resistance held permissible under the closed shop proviso. ${ }^{77}$ Since the union contract may be renewed, as in the Triboro case, against the will of the particular employees, attractive possibilities are offered for self-perpetuation by an inside union. ${ }^{78}$

Adoption of a strictly contractual approach to a problem largely political may be partially justified by the judicial tradition protecting contract rights of union and employer. On the other hand, it is open to criticism for complete refusal to consider the possibility that those rights have been modified by the Wagner Act. If a system of employee participation in industrial relations is desired, it is vital to define the extent to which the majority voice may be silenced by private contracts. While the existence of a closed

The court suggested three ways by which the employees might have freed themselves: either directly or through the officers of Amalgamated they might have given notice of termination; or they might have instituted a representation proceeding within the period for notice. The adequacy of these methods may be questioned in the light of the obvious split between the employees and Amalgamated, and of the danger attending open reballion by a group of employees under a closed shop contract.

76. 286 N. Y. $314,318,322,36$ N. E. (2d) $315,316,318$ (1941).

77. See note 42 supra. It is on this issue that the Supreme Court has granted certiorari in the Vacumm Cleaners case. See (1941) 10 U. S. L. Wern 3139.

78. See Analysis: Employecs' Right to Change Unions Limited by Contract, 8 Lad. REL. Rep. (Supp. to No. 24, Aug. 11, 1941) 4, and a similar adverse reaction to the Triboro decision in "No Escape for Worker," N. Y. Sun, Aug. 12, 1941, p. 15, cols. 3-4 (David Lawrence). 
or preferential shop contract adds to the doctrinal objections to administrative action, it also points with additional clarity the need for such action. Further, although the decisions are rendered in the name of contractual and industrial stability, the courts themselves have noticed that denial of employee desires as to representation can be a potent incentive to resort to the strike weapon. ${ }^{79}$

But in the absence of a definitive Supreme Court ruling, ${ }^{80}$ there seems little likelihood that labor contract procedure in the courts will be brought into harmony with Board practice. ${ }^{81}$ Even though desirable solutions of the problem may eventually develop in the courts, the importance of the issues justifies more immediate legislative action. Possible forms for amending the Wagner Act are varied. For example, substitution, rejected by the courts, may be accomplished by legislative fiat. But the anomalies arising in the application of a principle of substitution to a closed shop situation illustrate its inconclusive and makeshift character. In practice it cannot accomplish the maintenance of contractual stability, which is its theoretical justification.

More satisfactory would be direct enactment of some modification of the current philosophy of the Board. Official restriction of the life of labor agreements to a one-year term, coupled with a requirement for annual reexamination of employee union support, would eliminate existing possibilities for freezing representation. Correlative enactment of the inviolability of agreements during the one-year period would meet the requirement of reasonable stability. Agreements for a longer term might be permitted, subject as a matter of law to termination after an initial protective period on notice or by a change in representative. There are indications of the political feasibility of the adoption of this method of solution. Followed in practice by the Board, it is implicit in the amendments proposed by the AFL, ${ }^{82}$ and

79. The court in the Triboro case rejects the Board's methods as putting a premium on industrial unrest by subjecting the contract to revision once each ycar. It acknowledges, however, that refusal to grant the Board its asserted power tends "to compel the new union to resort to a strike to enforce its demands." But since "the cmployer will be free to discharge those workers who are unwilling to be bound by the contracts," all objections to strikes are apparently dispelled. 286 N. Y. 314, 322, 36 N. E. (2d) 315, 318 (1941). See "Triboro Coach Ruling Seen as Aid to Stability" N. Y. Herald Tribune, Aug. 3, 1941, § II, p. 9, col. 6.

80. Although certiorari was granted in the Vaculmm Cleancrs case apparently to examine the extent of employer assistance permissible under a closed shop contract, there is a possibility that the Supreme Court may decide on the broader question of the right of the company in any case to enter a contract after notice of a dispute as to representation.

81. The rehearing requested in the Triboro case, even if granted, would probably not result in a reversal of the court's position on change of representative during the life of a contract. The ground for the motion is an alleged mistake of fact in the court's consideration, and thus applies to the application of the rule laid down by the court, not to the rule itself.

82. See note 39 supra. 
has the modified support of the CIO. $\$ 3$ If this proposal proves impractical or inadequate in protecting freedom of choice of representative, resort may be had to broader controls. The establishment of a continuously available governmental administration of collective agreements, for example, would permit the adjustment of contract rights to changes in representative accurding to the requirements of each case. ${ }^{8 t}$ Legislative adoption of standard agreements to cover entire industries with the effect of $\mathrm{law}^{85}$ a still further step, would remove the whole problem from control by union contract. Practical and political objections to these measures, however, re-emphasize the desirability of confining the methods of solving the problem to presently available techniques.

83. See Rosexfarb, The National Lazor Poliey (1940) 272.

84. This is provided for, as to contracts covering railrosd workers, by Sectiuns 2 , 3 and 6 of the Railway Labor Act, $4 \$$ STAT. 1185, 45 U. S. C. $\$ \S 151-64$ (1934).

85. For this procedure in foreign countries, see Hamburger, The Exscrsion of $\mathrm{Col}_{\mathrm{O}}$ lective Agreements to Cozer Entire Trades and Industrics (1939) 40 I:s. LAd. REw. 153; Legalization of Collectioc Agrcoments in Forcign Combries (1936) 43 Mo:TnLy Lub. REv. 398. 